\title{
Study of Phase Transformations In API 5L X80 Steel in Order to Increase its Fracture Toughness
}

\author{
Igor Rafael Vilarouco Pedrosa ${ }^{\mathrm{a}, \mathrm{b} *}$, Renato Soares de Castro ${ }^{\mathrm{a}, \mathrm{b}}$, \\ Yogendra Prasad Yadava ${ }^{\mathrm{a}}$, Ricardo Artur Sanguinetti Ferreira ${ }^{\mathrm{a}}$
}

\author{
${ }^{\mathrm{a}}$ Departamento de Engenharia Mecânica, Universidade Federal de Pernambuco - UFPE, \\ Av. Acadêmico Hélio Ramos, s/n, Cidade Universitária, CEP 50740-530, Recife, PE, Brasil \\ 'Instituto Federal de Educação, Ciência e Tecnologia de Pernambuco - IFPE, Av. Professor Luiz Freire, \\ 500, Cidade Universitária, CEP 50740-540, Recife, PE, Brasil
}

Received: July 12, 2012; Revised: October 14, 2012

\begin{abstract}
Phase transformations in API 5L X80 steel were studied in different thermomechanical sequences with a view to increasing the fracture toughness of this steel. Dilatometry tests performed on the quenched steel detected a phase transformation occurred, during heating, in the temperature range 593-618 K. This phase transformation was identified as the dissolution of M-A islands. Based on preliminary dilatometric tests, ten thermal and thermomechanical treatments were performed on X80 steel samples. Initially, the material was hot rolled and quenched and only quenched. On the material without deformation, aging was also performed at temperatures of $603,673,723,773,823$ and $873 \mathrm{~K}$. These treatments resulted in the formation of the acicular ferrite constituent, among others. Tensile tests showed that the aging treatments produced reductions in yield strength and increases in the elongation and toughness of X80 steel. All the treatments resulted in an increase in the tensile strength of steel.
\end{abstract}

Keywords: API 5L X80 steel, phase transformation, toughness

\section{Introduction}

The need for steels used in structures and vessels to transport fluids like oil and gas is generating a rapid development in microalloyed steels. Today, gases are transported in pipelines in severe environments and under usage conditions that need to consider temperature, pressure, acidity, friction, weldability, installation and maintenance. Market conditions oblige high strength steels with good toughness at low temperatures and better weldability to be produced ${ }^{1}$.

The increase in demand for natural gas has compelled distribution centers to operate with ever higher pressures, requiring the use of steels of ultra-high strength. The increase in the strength of steel for pipelines allows the thickness of pipeline walls to be significantly reduced, with a consequent reduction in weight. However, it is important that the increase in yield strength is not accompanied by a decrease in fracture toughness and formability, because a decrease in toughness will stimulate stress-induced fracture and a decrease in formability will cause difficulties in plastic deformation (for example, tube bending). Thus, high strength in combination with high toughness and formability are important requirements of the pipeline industry ${ }^{2}$.

High Strength Low Alloy Steels - HSLA form a very important class of steels that are suitable for a wide variety of structural applications. Pipeline steels form a particular class of HSLA with high mechanical strength,

*e-mail: ivilarouco@yahoo.com.br good weldability and low hardenability, and thus are suitable for manufacturing pipes used in transporting many different kinds of fluids under pressure, such as oil and its derivatives $^{3-6}$.

The HSLA steels are microalloyed steels that present one typical microstructure of ferrite-pearlite in their original structure. Its chemical composition is similar to a low-carbon steel, but with additions of elements of alloying $(\mathrm{Nb}, \mathrm{Ti}$ and $\mathrm{V})$ to ensure superior mechanical properties?

Microstructures with a significant proportion of acicular ferrite (AF) reportedly have an optimized combination of mechanical properties in $\mathrm{Nb}$-Ti steels for pipelines when compared to alloys with predominantly bainitic structures $^{8}$. The matrix of acicular ferrite is usually characterized by its thin, non-equiaxed, morphology and intertwined, non-parallel laths in various sizes, which are randomly distributed, which is often described as a "chaotic arrangement" of laths ${ }^{8}$.

Dilatometry is one of the most powerful techniques for the study of solid-solid phase transformations in steels, because it allows real time monitoring of how the transformations evolve, in terms of dimensional changes, that occur in the sample by applying a thermal cycle. It is also one of the classic techniques, together with differential thermal analysis and quantitative analysis of microstructures, most commonly used to determine the temperatures of phase transformation in steels, both in heating and cooling 9 . 


\section{Material and Methods}

The material used in this study was API 5L X80 steel extracted from pipes that are $800 \mathrm{~mm}$ in diameter and $19.1 \mathrm{~mm}$ thick, produced by thermomechanical controlled rolling (TMCR). According to the manufacturer of this steel, the yield strength and tensile strength of this material are $555 \mathrm{MPa}$ and $625 \mathrm{MPa}$, respectively. The chemical composition of the steel is shown in Table 1.

For the simulation of thermal cycles, dilatometry tests were performed in a DIL 402 PC dilatometer. To conduct these tests, 20 cylindrical samples were manufactured from API 5L X80 steel tubes by machining operations, after which the average sizes of the samples were $5 \mathrm{~mm}$ in diameter and $25 \mathrm{~mm}$ in length.

Based on preliminary dilatometric tests, rectangular samples were fabricated for thermal and thermomechanical treatments through machining operations. The average sizes of these samples were $10 \times 19 \times 100 \mathrm{~mm}$.

10 thermal and thermomechanical treatments were performed. All the treatments started with heating the steel to $1223 \mathrm{~K}$. In heat treatment 1 , the material was austenitized for 15 minutes, hot rolled with a reduction of $15 \%$ followed by quenching in water, as shown schematically in Figure 1. In heat treatments 2 and 3 , the material was austenitized for 15 and 60 minutes, respectively, followed by quenching in water, as shown schematically in Figure 2. Heat treatments

Table 1. Chemical composition of API 5L X80 steel.

\begin{tabular}{|c|c|}
\hline Alloying element & $\begin{array}{c}\text { Concentration in weight } \\
(\%)\end{array}$ \\
\hline $\mathrm{C}$ & 0.03 \\
\hline $\mathrm{S}$ & 0.004 \\
\hline $\mathrm{N}$ & 0.0065 \\
\hline $\mathrm{O}$ & NR \\
\hline $\mathrm{Al}$ & 0.029 \\
\hline $\mathrm{Si}$ & 0.21 \\
\hline $\mathrm{P}$ & 0.016 \\
\hline $\mathrm{Ti}$ & 0.015 \\
\hline $\mathrm{V}$ & 0.025 \\
\hline $\mathrm{Cr}$ & 0.161 \\
\hline $\mathrm{Mn}$ & 1.76 \\
\hline $\mathrm{Ni}$ & 0.014 \\
\hline $\mathrm{Cu}$ & 0.01 \\
\hline $\mathrm{Nb}$ & 0.069 \\
\hline Mo & 0.189 \\
\hline B & 0.0001 \\
\hline $\mathrm{Ca}$ & 0.003 \\
\hline $\mathrm{Nb}+\mathrm{V}+\mathrm{Ti}$ & 0.11 \\
\hline $\mathrm{V}+\mathrm{Nb}$ & 0.09 \\
\hline $\mathrm{Cr}+\mathrm{Ni}+\mathrm{Cu}+\mathrm{Mo}$ & 0.37 \\
\hline $\mathrm{Al} / \mathrm{N}$ & 4.6 \\
\hline $\mathrm{C}+\mathrm{Mn} / 5$ & 0.38 \\
\hline $\begin{array}{l}\mathrm{Pcm}=\mathrm{C}+\mathrm{Si} / 30+(\mathrm{Mn}+\mathrm{Cr}+\mathrm{Cu}) \\
/ 20+\mathrm{Ni} / 60+\mathrm{Mo} / 15+\mathrm{V} / 10+\mathrm{B} * 5\end{array}$ & 0.15 \\
\hline $\begin{array}{c}\mathrm{CE}=\mathrm{C}+\mathrm{Mn} / 6+(\mathrm{Cr}+\mathrm{Mo}+\mathrm{V}) \\
/ 5+(\mathrm{Ni}+\mathrm{Cu}) / 15\end{array}$ & 0.40 \\
\hline
\end{tabular}

2 and 3 were performed in order to evaluate the influence of austenitizing time on the toughness of the steel. In heat treatments 4, 5, 6, 7 and 8, the material was austenitized for 15 minutes, quenched and aged at temperatures of 673 , $723,773,823$ and $873 \mathrm{~K}$, respectively, for 30 minutes, as shown schematically in Figure 3. In heat treatments 9 and 10 , the material was austenitized for 15 minutes, quenched and aged at a temperature of $603 \mathrm{~K}$ for 5 and 30 minutes, respectively, as shown schematically in Figure 4.

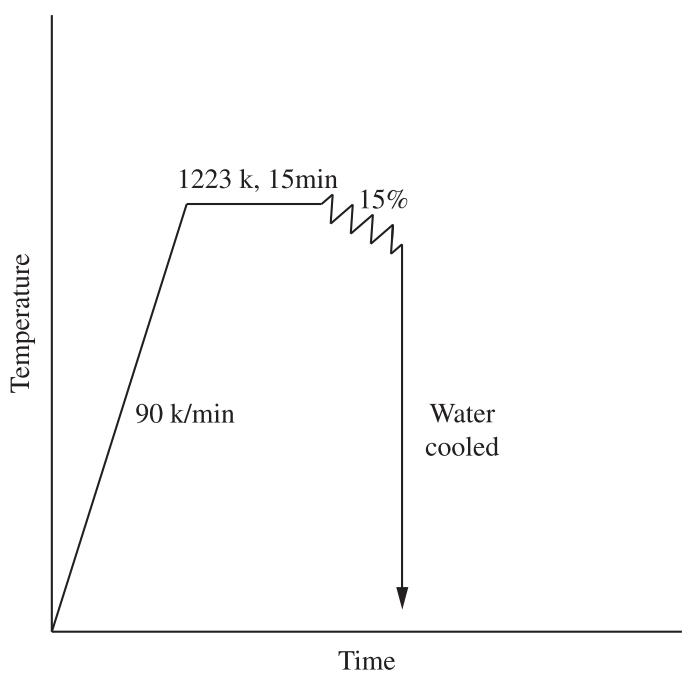

Figure 1. Schematic diagram of treatment 1.

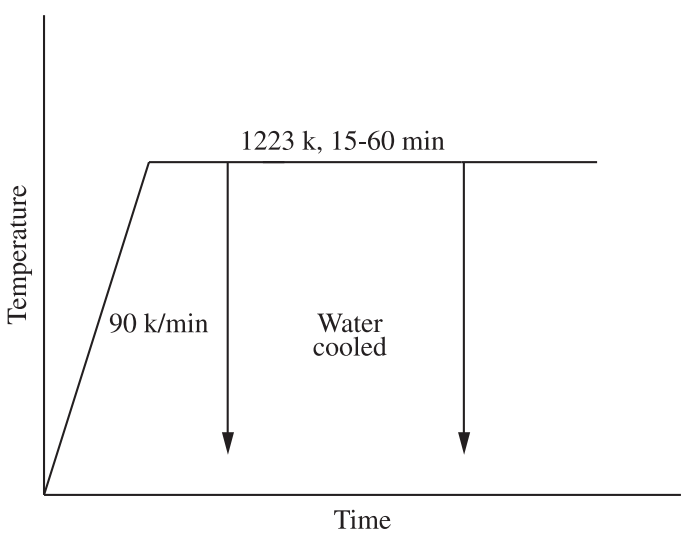

Figure 2. Schematic diagram of treatments 2 and 3.

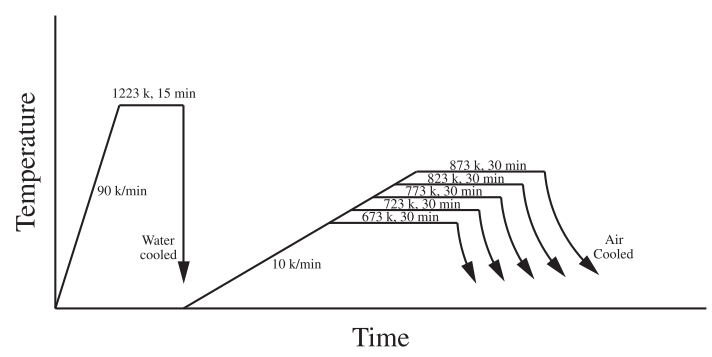

Figure 3. Schematic diagram of treatments 4, 5, 6, 7 and 8 . 
The microstructures associated with these different treatments were characterized by scanning electron microscopy (SEM). The mechanical properties were obtained by means of tensile tests. The tensile samples were fabricated based on the ASTM E $8^{[10]}$ standard. The tensile tests were performed on a hydraulic-servant tensile machine with a load cell of $100 \mathrm{kN}$, a head displacement speed of $1 \mathrm{~mm} / \mathrm{min}$ being used in all tests. The testing parameters were controlled by a commercial software program. All tests were performed at ambient temperature (298 K).

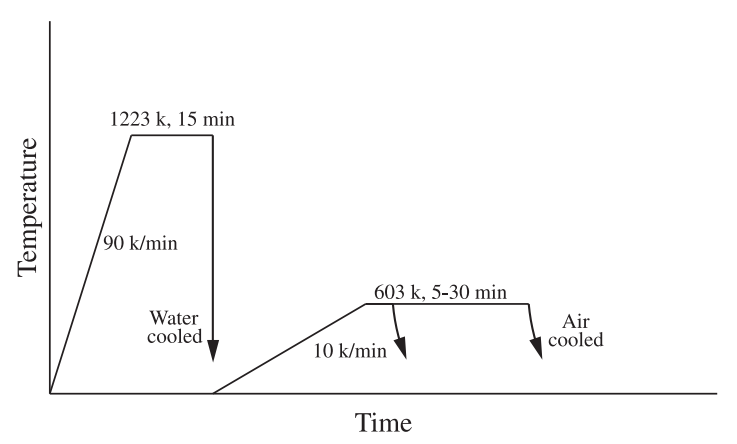

Figure 4. Schematic diagram of treatments 9 and 10.

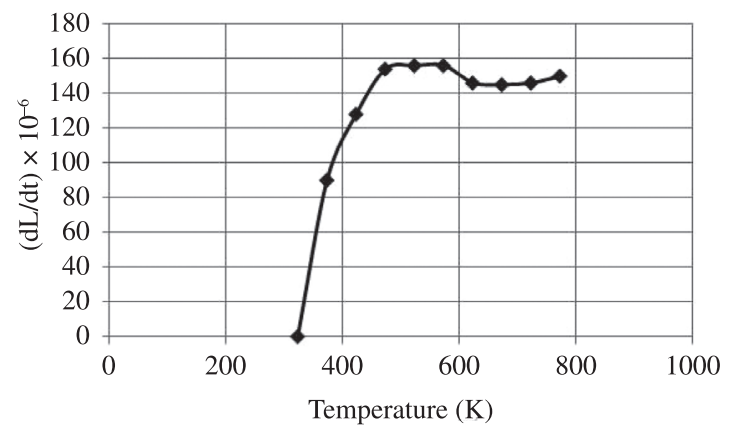

Figure 5. Dilatometric test of the sample heated with a rate of $10^{\circ} \mathrm{K} / \mathrm{min}$, aged at $773 \mathrm{~K}$ for 30 minutes and cooled in still air.

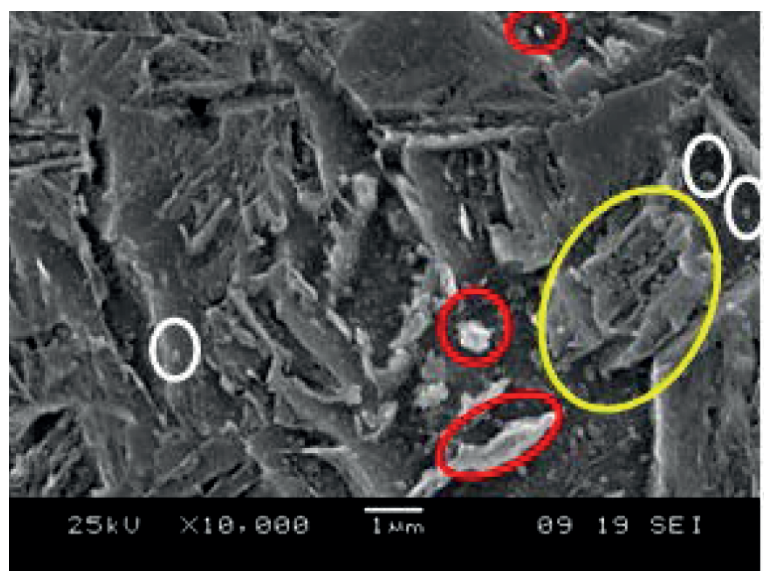

(a)

\section{Results and Discussion}

Figure 5 presents a graph of the derivative function of the material expansion as a function of temperature with regard to the material treated as per the schematic diagram of Figure 3 (heat treatment 6). In this dilatometric test, the sample, after being quenched, was heated at a heating rate of $10 \mathrm{~K} / \mathrm{min}$ up to $773 \mathrm{~K}$, kept at this temperature for 30 minutes and cooled in still air. On analyzing the graph, it can be seen that the derivative function of the material expansion suffers a small reduction during the heating of the material in the temperature range $593-618 \mathrm{~K}$. This reduction characterizes the occurrence of a phase transformation. This phase transformation was also observed in dilatometric tests referring to treatments 4, 5, 7 and 8 (diagram of Figure 3) and was investigated by means of scanning electron microscopy.

Figure 6a shows a micrograph of the sample austenitized for 15 minutes and quenched in water. This image displays the presence of retained austenite (yellow ellipse), granular ferrite (white ellipses) and a large number of M-A islands (red ellipses). The presence of M-A islands was expected since González et al. ${ }^{11}$, when they performed heat treatments with continuous cooling on API 5L X80 steel, the composition of which was $0.0679 \% \mathrm{C}, 1.83 \% \mathrm{Mn}$, $0.104 \%(\mathrm{Nb}+\mathrm{Ti}+\mathrm{V}), 0.193 \% \mathrm{Si}, 0.189 \% \mathrm{Cr}, 0.245 \%$ Mo, $0.0243 \% \mathrm{Al}, 0.0030 \% \mathrm{P}$, observed an increase in the volumetric fraction of M-A islands for higher cooling rates.

Figure $6 \mathrm{~b}$ shows a micrograph of the sample austenitized for 15 minutes, quenched in water and aged at $603 \mathrm{~K}$ for 5 minutes (diagram of Figure 4). This image displays the presence of retained austenite (yellow ellipses) and granular ferrite (white ellipses), constituents already observed in the material austenitized for 15 minutes and quenched in water (Figure 6a). However, the M-A islands seen in the image of Figure 6a no longer appear in the micrograph of the material austenitized for 15 minutes, quenched in water and aged at $603 \mathrm{~K}$ for 5 minutes (Figure 6b). Thus, it can be said that the phase transformation observed during heating of the material after quenching in the temperature range 593-618 K (Figure 5) can be associated with the dissolution of M-A islands.

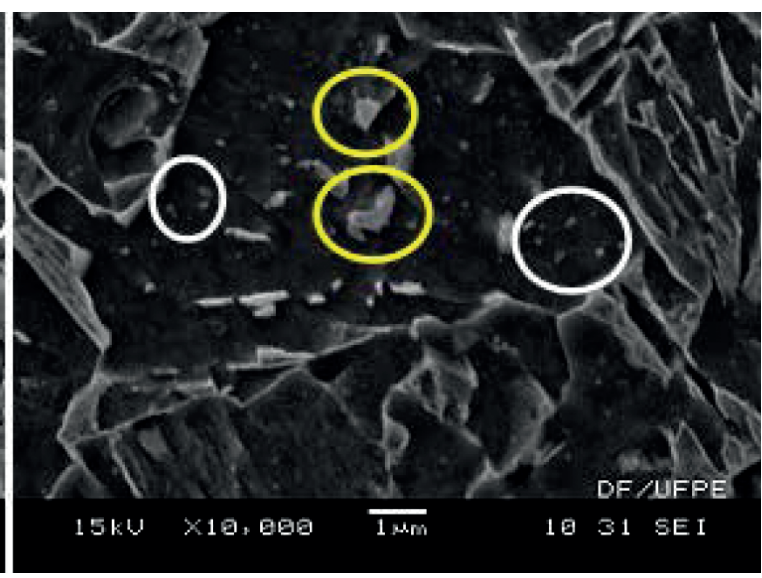

(b)

Figure 6. Micrographs of the sample austenitized for 15 minutes and quenched (a) and the sample austenitized for 15 minutes, quenched and aged at $603 \mathrm{~K}$ for 5 minutes (b). 
Figure 7a shows a micrograph of the sample austenitized for 15 minutes and quenched in water (diagram of Figure 2). This image displays the presence of thin, non-equiaxed ferrite consisting of interwoven non-parallel laths, featuring a predominance of acicular ferrite. This figure also shows the existence of polygonal ferrite (green ellipses), in a lesser amount and the thin granular nature of an acicular structure.

Cizek et al. ${ }^{12}$, when they performed heat treatments with continuous cooling on API 5L X80 steel, the composition of which was $0.065 \% \mathrm{C}, 0.29 \% \mathrm{Si}, 1.5 \% \mathrm{Mn}, 0.015 \%$ $\mathrm{P}, 0.003 \% \mathrm{Al}, 0.28 \% \mathrm{Mo}, 0.076 \% \mathrm{Nb}$ and $0.020 \% \mathrm{Ti}$, found that, at high cooling rates $(95 \mathrm{~K} / \mathrm{s})$, a microstructure consisting of bainitic ferrite and a small amount of martensite was obtained. The difference between the microstructure obtained by Cizek et al. ${ }^{12}$ and the microstructure obtained in this study can be justified by the higher carbon content $(0.065 \%)$ of the steel used by Cizek et al. ${ }^{12}$ compared to the $0.03 \%$ carbon content of the steel used in this study.

Figure $7 \mathrm{~b}$ shows a micrograph of the sample austenitized for 60 minutes and quenched in water (diagram of Figure 2). This figure shows that the structure consists of a mixture of acicular ferrite and polygonal ferrite (green ellipses). This figure also shows the presence of retained austenite (yellow ellipses), in a lesser amount. On comparing Figures 7a, b, it may be affirmed that the sample austenitized for 60 minutes and quenched in water has a smaller amount of acicular ferrite and a grain coarser than the sample austenitized for 15 minutes and quenched in water. The longer austenitizing time (60 minutes) may have caused the grain to grow, thus making the grain coarser. The longer treatment time (60 minutes) may also have eliminated some defects which would promote the formation of acicular ferrite, which sees to it that this structure presents a smaller amount of acicular ferrite than the material austenitized for 15 minutes.

Figure 8 shows micrographs of the material austenitized for 15 minutes, quenched in water and aged at temperatures $673 \mathrm{~K}$ (a), $723 \mathrm{~K}$ (b), $773 \mathrm{~K}$ (c), $823 \mathrm{~K}$ (d) and $873 \mathrm{~K}$ (e) for 30 minutes (diagram of Figure 3 ). Using these micrographs, it's observed the presence of interwoven non-parallel ferrite laths distributed randomly, which characterize the existence of acicular ferrite, as well as the presence of small granules distributed throughout the structure, characterizing the existence of granular ferrite. It can also be seen that by increasing the aging temperature of X80 steel, the volume fraction of granular ferrite increased, the ferrite laths coalesced resulting in wider laths and there was an enrichment of solute in the boundaries of the ferrite laths.

Similarly, Niu et al. ${ }^{13}$ performed heat treatments on an X80 steel which comprised $0.072 \%$ C, $0.19 \% \mathrm{Si}, 1.70 \%$ Mn, $0.0026 \%$ S, $0.0099 \%$ P, $0.23 \%$ Ni, $0.085 \%$ Cr, $0.16 \%$ $\mathrm{Cu}, 0.015 \% \mathrm{Ti}, 0.20 \% \mathrm{Mo}, 0.05 \% \mathrm{Nb}$ and $0.027 \% \mathrm{~V}$ and observed that by increasing the aging temperature of X80 steel, bainite ferrite laths merged to form wide laths and the boundaries of laths became fuzzy.

Figure 9 shows the yield strength and tensile strength of the API 5L X80 steel "as received" and after thermal and thermomechanical treatments. The values shown in Figure 9 were obtained from the simple arithmetic average of the values of the three tests. The tests were performed on the X80 steel under the following conditions:

- (A) Material "as received";

- (B) Material austenitized (15 minutes), rolled (15\%) and quenched;

- (C) Material austenitized (15 minutes) and quenched;

- (D) Material austenitized (60 minutes) and quenched;

- (E) Material austenitized (15 minutes), quenched and aged at $603 \mathrm{~K}$ for 5 minutes;

- (F) Material austenitized (15 minutes), quenched and aged at $603 \mathrm{~K}$ for 30 minutes;

- (G) Material austenitized (15 minutes), quenched and aged at $673 \mathrm{~K}$ for 30 minutes;

- (H) Material austenitized (15 minutes), quenched and aged at $723 \mathrm{~K}$ for 30 minutes;

- (I) Material austenitized (15 minutes), quenched and aged at $773 \mathrm{~K}$ for 30 minutes;

- (J) Material austenitized (15 minutes), quenched and aged at $823 \mathrm{~K}$ for 30 minutes; and

- (K) Material austenitized (15 minutes), quenched and aged at $873 \mathrm{~K}$ for 30 minutes.

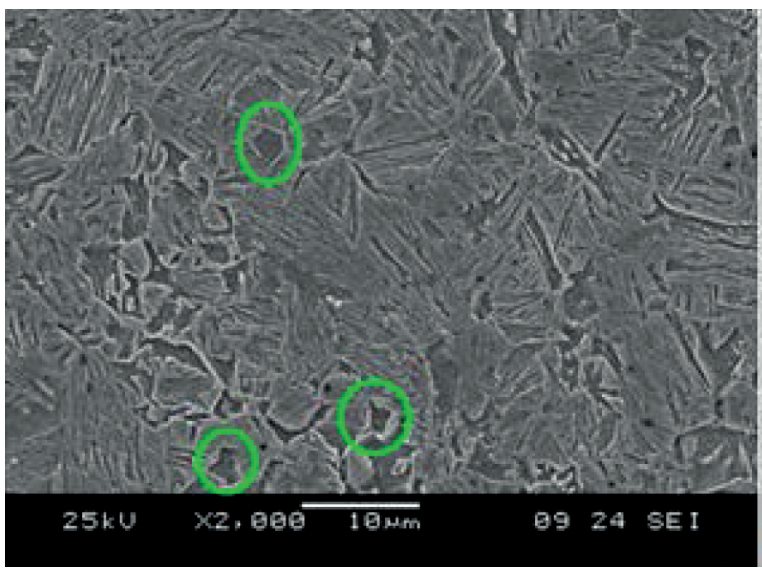

(a)

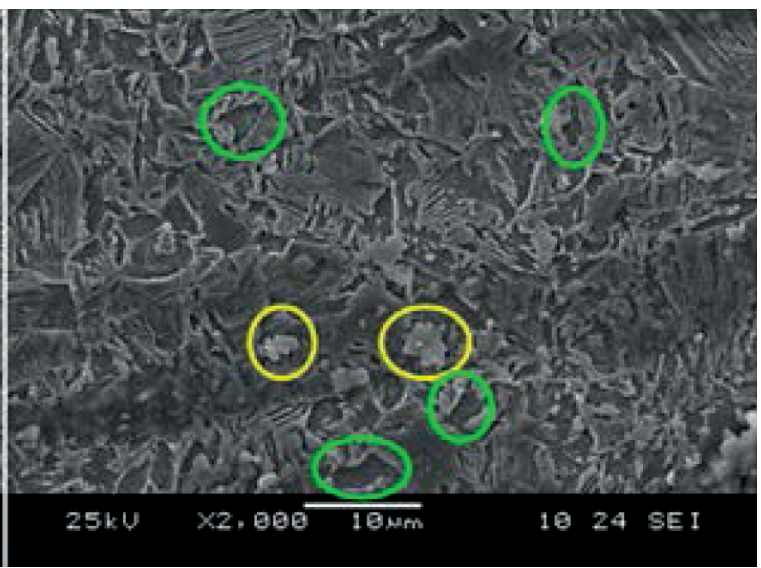

(b)

Figure 7. Micrographs of the sample austenitized for 15 minutes (a) and 60 minutes (b) and quenched in water. 


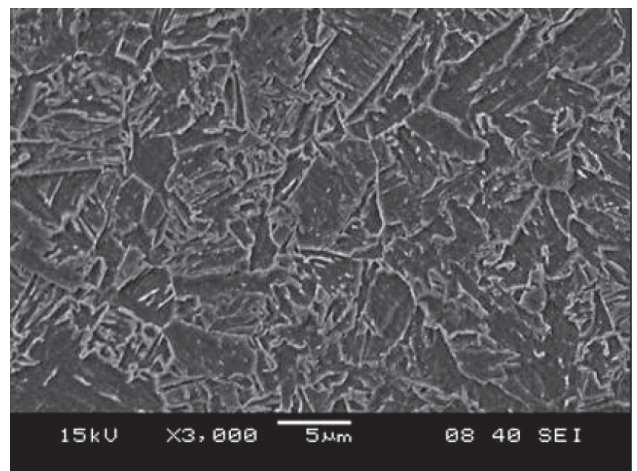

(a)

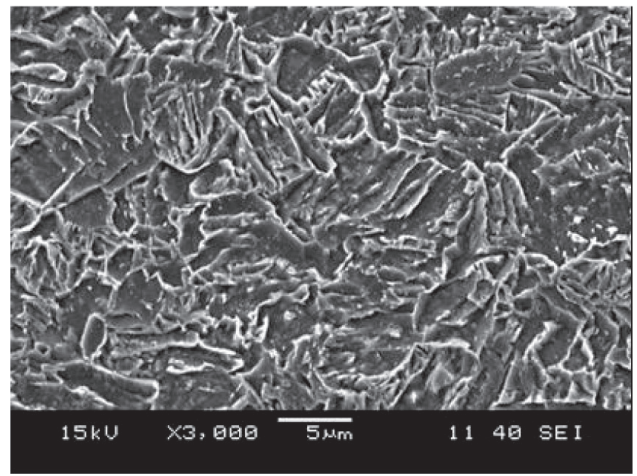

(c)

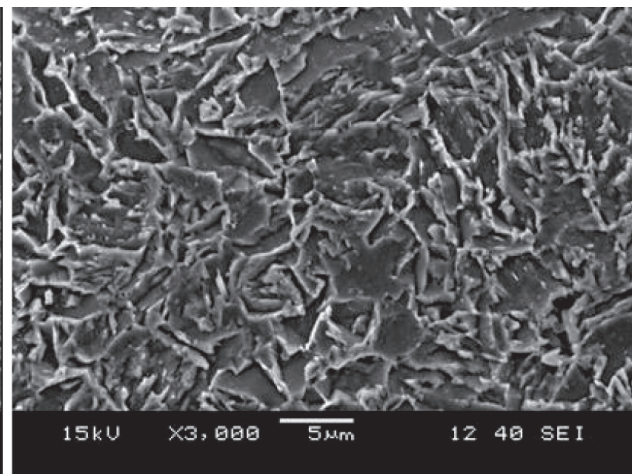

(b)

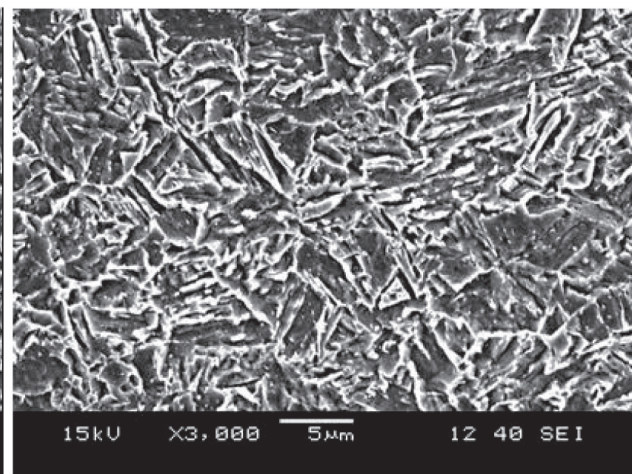

(d)

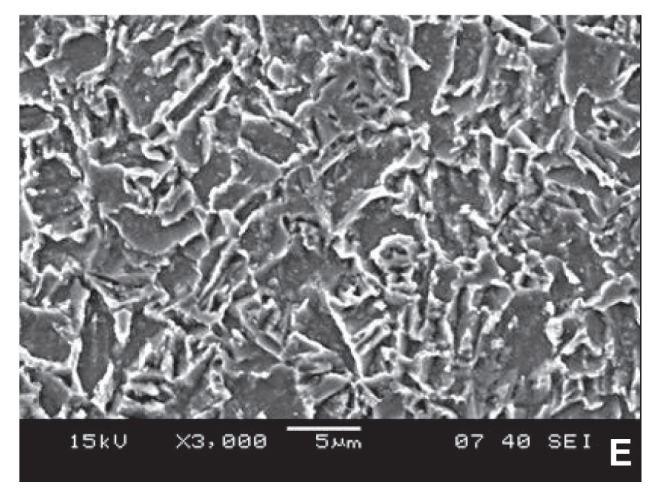

(e)

Figure 8. Micrographs of the material austenitized for 15 minutes, quenched in water and aged at temperatures of $673 \mathrm{~K}$ (a), $723 \mathrm{~K}$ (b), $773 \mathrm{~K}$ (c), $823 \mathrm{~K}$ (d) and $873 \mathrm{~K}$ (e) for 30 minutes.

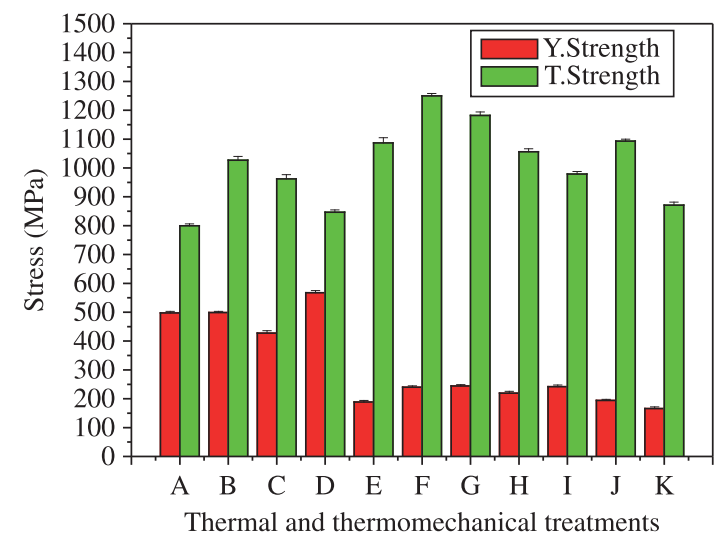

Figure 9. Yield and tensile strengths of API 5L X80 steel "as received" and after thermal and thermomechanical treatments.
All thermal and thermomechanical treatments performed on API 5L X80 steel produced increases in tensile strength in relation to the material "as received", which can be attributed to the formation of acicular ferrite since, according to Lee et al. ${ }^{14}$, a microstructure of acicular ferrite has the potential of combining high strength and high toughness. This occurs because the plates of acicular ferrite nucleate intra-granularly on non-metallic inclusions within large austenite grains and then they diffuse in many different directions from those inclusions while maintaining an orientation relationship with the austenite. A crack therefore would have to follow a more tortuous path through a microstructure of acicular ferrite ${ }^{14}$.

The materials aged at temperatures 603, 673, 723, 773,823 and $873 \mathrm{~K}$ showed large reductions in their yield strength in relation to the material austenitized for 
15 minutes and quenched in water. This reduction can be attributed to the dissolution of M-A islands (Figures 5 and 6), since, according to Chen et al. ${ }^{15}$, yield strength is mainly decided by the barriers to movement of dislocation line and deviate from M-A islands.

In Figure 9, the sixth red and green column (F) corresponds to the yield strength and tensile strength, respectively, of the material austenitized for 15 minutes, quenched in water and aged at $603 \mathrm{~K}$ for 30 minutes. It is easy to see that this heat treatment resulted in the greatest tensile strength among the treatments performed. This can be justified by the dissolution of M-A islands (Figures 5 and 6), since this constituent functions as a site for the nucleation of cracks. The aging temperature of $603 \mathrm{~K}$, in addition to dissolving the M-A islands, is not high enough to reduce the density of dislocation line significantly. Thus, the result was a high tensile strength.

When Zhou et al. ${ }^{16}$ performed heat treatments on a Ultra-High Strength X120 Pipeline Steel comprising 0.05\% C, $0.31 \% \mathrm{Si}, 1.99 \% \mathrm{Mn}, 0.008 \% \mathrm{P}, 0.002 \% \mathrm{~S}, 0.27 \% \mathrm{Mo}$, $0.62 \% \mathrm{Ni}, 0.04 \% \mathrm{Al}, 0.08 \%(\mathrm{Nb}+\mathrm{Ti}), 0.53 \%(\mathrm{Cr}+\mathrm{Cu})$, and $0.0017 \% \mathrm{~B}$, they affirmed that by increasing the aging temperature of the steel, the structure of laths coarsened, the density of dislocation line decreased and the barrier effect of the microstructure for micro-cracks decreased sharply, thus decreasing the tensile strength. The results obtained by Zhou et al. ${ }^{16}$ were similar to those obtained in this study, since by increasing the aging temperature of the steel studied in this article, it was observed that the ferrite laths coalesced, resulting in wider laths of various sizes (Figure 8), thereby decreasing the tensile strength of the steel (Figure 9).

Figure 10 shows the elongations reached by API 5L X80 steel "as received" and after thermal and thermomechanical treatments. The values shown in Figure 10 were obtained from the simple arithmetic average of the values of the three tests. The elongations were obtained for the API 5L X80 steel under the same conditions mentioned previously.

It is easy to see, from Figure 10, that the shortest elongation $(8.7 \%)$ was obtained with the material austenitized for 60 minutes and quenched in water (D). This

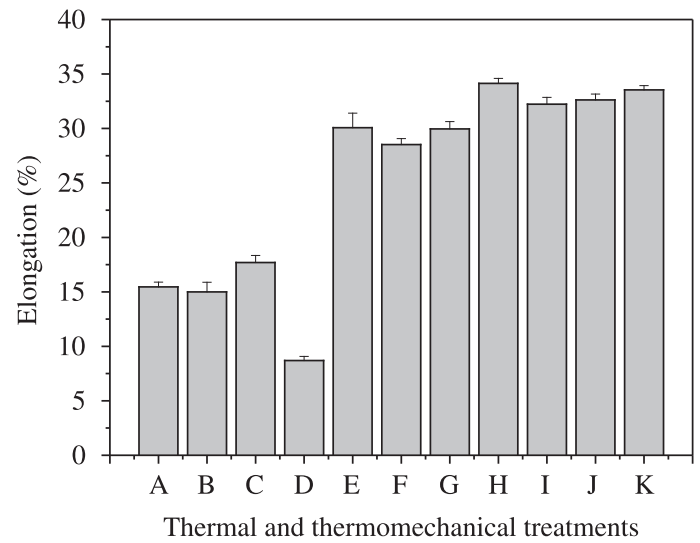

Figure 10. Elongations of API 5L X80 steel "as received" and after thermal and thermomechanical treatments. low elongation can be justified by the longest austenitizing time (60 minutes) of this heat treatment. This length of austenitizing time (60 minutes) may have caused the grain to grow, thus making it coarser (Figure 7), which results in a decrease in the elongation result for the material.

Figure 10 also shows that all heat treatments with stages of aging at $603,673,723,773,823$ and $873 \mathrm{~K}$ resulted in large elongations. The aging process reduces the density of dislocation line, thus making the steel more ductile and thereby increasing the elongation results for the material.

When Zhou et al. ${ }^{16}$ performed heat treatments on a X120 Steel, they affirmed that by increasing the aging temperature of the steel, the density of defects decreased and deformation increased. This behavior was also observed in the results obtained in this study (Figure 10), because by increasing the aging temperature of the X80 steel, the density of the dislocation line decreased and the elongation results increased. This increase in elongation may also be justified by the change in morphology of the material since, by increasing the aging temperature of the X80 steel, the volume fraction of granular ferrite, a constituent which is characterized by having good ductility, increased (Figure 8).

When Silva et al. ${ }^{17}$ performed heat treatments on a API 5L X70 Steel comprising $0.03 \%$ C, $0.14 \%$ Si, $1.52 \%$ $\mathrm{Mn}, 0.29 \% \mathrm{Cr}, 0.23 \% \mathrm{Cu}, 0.09 \% \mathrm{Nb}, 0.01 \% \mathrm{Ti},<0.01 \% \mathrm{~V}$, $<0.01 \% \mathrm{~W}, 0.01 \% 0.04 \% \mathrm{Mo}, 0.15 \% \mathrm{Ni}$, and $0.03 \% \mathrm{Al}$, they concluded that the granular structure formed as a result of quick cooling, without rolling, increased the elongation results for the steel.

Figure 11 shows the indicative values of toughness achieved by API 5L X80 steel "as received" and after thermal and thermomechanical treatments. These indicative values of toughness were obtained by the areas under the Stress $(\sigma)$ X Strain (\%) curves derived from the same tensile tests from which the yield and tensile strengths of the material were obtained. Therefore, the indicative values of toughness of API 5L X80 steel was obtained under the same conditions mentioned previously. The values shown in Figure 11 were obtained from the simple arithmetic average of the values of the three tests.

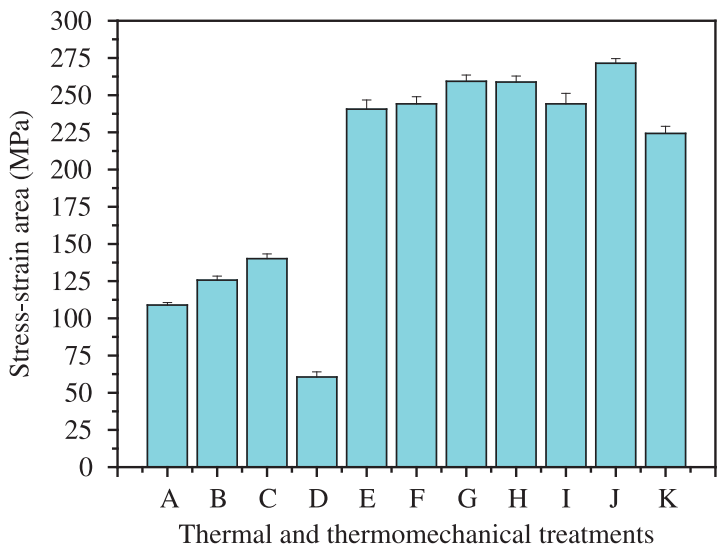

Figure 11. Toughness of API 5L X80 steel "as received" and after thermal and thermomechanical treatments. 
It is easy to see, from Figure 11, that the material austenitized for 60 minutes and quenched in water (D) showed the lowest indicative value of toughness (60.6 MPa) among the materials tested. This low toughness can be justified by the longer austenitizing time ( 60 minutes) of this heat treatment, which may have caused the grain to grow, thus making it coarser (Figure 7), and therefore the toughness of the material decreases.

All thermal and thermomechanical treatments performed on API 5L X80 steels, except those for austenitizing for 60 minutes followed by quenching, produced increases in their toughness in relation to the material "as received", which can be attributed to acicular ferrite and granular ferrite having formed.

Figure 11 also shows that all heat treatments with stages of aging at $603,673,723,773,823$ and $873 \mathrm{~K}$ resulted in large indicative values of toughness. The aging treatments besides decreasing the density of defects, resulted in the dissolution of M-A islands (Figures 5 and 6), thus decreasing the barriers to motion of the dislocation line and allowing the dislocation line to slide more easily. Thus, the aging process increases the mobility of the dislocation line and, consequently, increases the toughness of the material. Furthermore, the M-A islands function as a site for the nucleation of cracks which decreases the toughness of the material.

It can also be seen from Figure 11 that the material austenitized for 15 minutes, quenched in water and aged at $823 \mathrm{~K}$ for 30 minutes $(\mathrm{J})$ showed the highest indicative value of toughness (271.4 MPa) among the materials tested. The micrograph of this material revealed an enrichment of solute in the boundaries of the ferrite laths (Figure 8d). This enrichment may have caused a hardening by solid solution, which may justify the greater toughness of this material.

Niu et al. ${ }^{13}$ performed heat treatments on an X80 steel comprising $0.072 \% \mathrm{C}, 0.19 \% \mathrm{Si}, 1.70 \% \mathrm{Mn}, 0.0026 \% \mathrm{~S}$, $0.0099 \% \mathrm{P}, 0.23 \% \mathrm{Ni}, 0.085 \% \mathrm{Cr}, 0.16 \% \mathrm{Cu}, 0.015 \% \mathrm{Ti}$, $0.20 \% \mathrm{Mo}, 0.05 \% \mathrm{Nb}$ and $0.027 \% \mathrm{~V}$ and evaluated its toughness by Charpy impact tests conducted at different test temperatures. The heat treatments performed by Niu et al. ${ }^{13}$ were quenching followed by aging at temperatures of 823 , $873,923,973 \mathrm{~K}$ for 60 minutes. Impact tests performed by Niu et al. ${ }^{13}$ at a temperature of $293 \mathrm{~K}$ showed that the greatest impact on energy - in other words, the greatest toughness - was obtained with the material quenched and aged at temperature of $823 \mathrm{~K}$ for 60 minutes. Similarly, the

\section{References}

1. Ramírez MG, Gorni AA, Landgraf F, Ogata PH and Goldenstein H. Caracterização Microestrutural de um Aço API 5L-X80 através de Microdureza e Microscopia Ótica e Eletrônica. In: Anais do $62^{\circ}$ Congresso Anual da ABM - Internacional; 2007; Vitória. Vitória; 2007.

2. Shanmugam S, Ramisetti NK, Misra RDK, Hartmann J and Jansto SG. Microstructure and High Strength-Toughness Combination of a New $700 \mathrm{MPa}$ Nb-Microalloyed Pipeline Steel. Materials Science and Engineering A. 2008; 478:26-37. http://dx.doi.org/10.1016/j.msea.2007.06.003

3. Eldmann U, Freier K, Kügler J and Vlad CM. Mechanical and Toughness Properties of Separation-Free HSLA Line Pipe tests performed in this study $(298 \mathrm{~K})$ showed that the greatest toughness was obtained with material quenched and aged at $823 \mathrm{~K}$ for 30 minutes.

\section{Conclusions}

The dilatometric tests carried out on the quenched API 5L X80 steel showed that a phase transformation occurred during heating of the material in the temperature range $593-618 \mathrm{~K}$. This phase transformation was investigated by scanning electron microscopy and was identified as the dissolution of M-A islands formed during quenching of the material.

The micrographs of the materials austenitized for 15 minutes, quenched and aged at 673, 723, 773, 823 and $873 \mathrm{~K}$ for 30 minutes revealed the presence of acicular ferrite and granular ferrite. Increasing the aging temperature of the steel resulted in increasing the volume fraction of granular ferrite and enrichment of solute in the boundaries of the ferrite laths, thus increasing the toughness.

All thermal and thermomechanical treatments performed in API 5L X80 steel produced increases in tensile strength in relation to the material "as received". The greatest tensile strength was obtained with the material austenitized for 15 minutes, quenched and aged at $603 \mathrm{~K}$ for 30 minutes.

All heat treatments with stages of aging at 603,673 , $723,773,823$ and $873 \mathrm{~K}$ caused large reductions in the yield strength of the X80 steel. By increasing the aging temperature of the steel, the tensile strength decreased and the elongation results increased.

All heat treatments with stages of aging at $603,673,723$, 773,823 and $873 \mathrm{~K}$ produced increases in the elongation and toughness of the X80 steel mainly due to decreasing the density of dislocation line and the dissolution of M-A islands.

The highest toughness value was obtained with the material austenitized for 15 minutes, quenched and aged at $823 \mathrm{~K}$ for 30 minutes.

\section{Acknowledgements}

We'd like to thank CAPES (Coordenação de Aperfeiçoamento de Pessoal de Nível Superior) for the financial support to this work, as well as to Physics Department of Pernambuco Federal University for the scanning electron microscopy tests.

Steels for Artic Conditions. In: Proceedings of the Conference Proceedings HSLA Steels Technology and Application ASM; 1983; Philadelphia. Philadelphia; 1983. p. 733-741.

4. Gräf MK, Lorentz FK, Peters PA and Schwaab P. Relationship between Microstructure and Mechanical Properties of Thermo-Mechanically Treated Large-Diameter Pipe Steels. In: Proceedings of the HSLA Steels Technology and Applications - Conference Proceedings; 1983; Philadelphia. HSLA; 1983. p. 801-807.

5. Manohar PA and Chandra T. Continuous Cooling Transformation Behavior of High Strength Microalloyed Steels for Linepipe Applications. ISIJ International. 1998; 38:766-774. http:// dx.doi.org/10.2355/isijinternational.38.766 
6. Zhao MC, Yang K and Shan Y. The Effects of Thermo-Mechanical Control Process on Microstructures and Mechanical Properties of a Commercial Pipeline Steel. Materials Science and Engineering A. 2002; 335:14-20. http://dx.doi.org/10.1016/ S0921-5093(01)01904-9

7. Hippert Junior E. Investigação Experimental do Comportamento Dúctil de Aços API-X70 e Aplicação de Curvas de Resistência J-_a para Previsão de Colapso em Dutos. [Tese]. São Paulo: Escola Politécnica, Universidade de São Paulo; 2004.

8. Tang Z and Stumpf W. The Role of Molybdenum Additions and Prior Deformation on Acicular Ferrite Formation in Microalloyed Nb-Ti Low-Carbon Line-Pipe Steels. Materials Characterization. 2008; 59:717-728. http://dx.doi. org/10.1016/j.matchar.2007.06.001

9. García de Andrés C, Caballero FG, Capdevila C and Álvarez LF. Application of Dilatometric Analysis to the Study of Solid-Solid Phase Transformations in Steels. Materials Characterization. 2002; 48:101-111. http://dx.doi.org/10.1016/ S1044-5803(02)00259-0

10. American Society for Testing and Materials - ASTM. Standard Methods of Tension Testing of Metallic Materials. Philadelphia; 1984. E 8, Annual Book of ASTM Standards, v. 03.01, p. 130-150.

11. González MFR, Landgraf FJG, Goldenstein H and Gorni AA. Curva TRC e sua Caracterização Microestrutural para um Aço Microligado para Tubos API 5LX80. In: Anais do $18^{\circ}$ Congresso Brasileiro de Engenharia e Ciência dos Materiais - CBECiMat; 2008; Porto de Galinhas. Porto de Galinhas; 2008.
12. Cizek P, Wynne B, Hodgson P and Muddle B. Effect of Simulated Thermomechanical Processing on the Transformation Characteristics and Microstructure of an X80 Pipeline Steel. In: Proceedings of the International Conference on Super-High Strength Steels; 2005; Milano. Associazione Italiana di Metallurgia; 2005.

13. Niu J, Qi L, Liu Y, Ma L, Feng Y and Zhang J. Tempering Microstructure and Mechanical Properties of Pipeline Steel X80. Transactions of Nonferrous Metals Society of China. 2009; 19:s573-s578. http://dx.doi.org/10.1016/ S1003-6326(10)60111-2

14. Lee $\mathrm{CH}$, Bhadeshia HKDH and Lee HC. Effect of Plastic Deformation on the Formation of Acicular Ferrite. Materials Science and Engineering. 2003; A360:249-257.

15. Chen L, Kang Y, Li X, Wen DZ, Liu GM. Effect of Tempering Temperature on the Microstructure and Mechanical Properties of $600 \mathrm{MPa}$ Grade Low Carbon Bainitic Steel [J]. Journal of University of Science and Technology Beijing. 2009; 31(8):983.

16. Zhou M, Du L and Liu X. Relationship Among Microstructure and Properties and Heat Treatment Process of Ultra-High Strength X120 Pipeline Steel. Journal of Iron and Steel Research International. 2011; 18(3): 59-64. http://dx.doi. org/10.1016/S1006-706X(11)60038-1

17. Silva RJF, Antonino TS and Ferreira RAS. Correlação entre Aumentos Percentuais da Laminação e a Formação de Ferrita Acicular e Ferrita Granular em um Aço API 5L X70. In: Anais do CIBIM 10; 2011; Oporto. Oporto; 2011. 